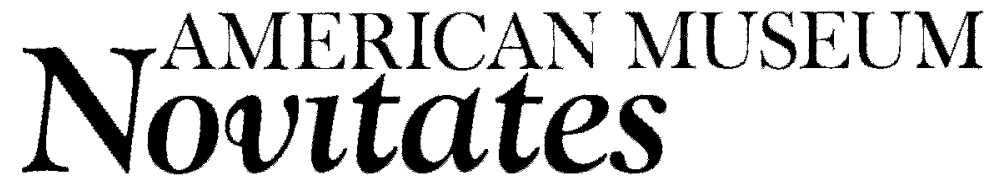

PUBLISHED BY THE AMERICAN MUSEUM OF NATURAL HISTORY CENTRAL PARK WEST AT 79TH STREET, NEW YORK, NY 10024 Number 3540, 12 pp., 5 figures, 1 table

December 7, 2006

\title{
Two Wasp Families Rare in the Fossil Record (Hymenoptera): Perilampidae and Megaspilidae from the Miocene of Spain
}

\author{
ENRIQUE PEÑALVER ${ }^{1}$ AND MICHAEL S. ENGEL ${ }^{2,3}$
}

\begin{abstract}
Three new species of parasitoid wasp are described and figured from Early Miocene (Early Burdigalian) compression fossils from Rubielos de Mora Basin, Spain. These wasps are significant as they are representative of two families exceedingly rare in the fossil record. The first is a species of the family Perilampidae (Chalcidoidea) and, aside from an old and unconfirmed record of an undescribed Perilampus in Baltic amber, is the only documented fossil of this lineage. Perilampus renzii, new species, is described from a single female. The remaining two species are both of the family Megaspilidae (Ceraphronoidea), which is otherwise known in the fossil record solely from a paucity of species preserved in fossil resins. Conostigmus lazaros, new species, and $\boldsymbol{C}$. chthonios, new species, are distinguished from each other as well as modern congeners.
\end{abstract}

\section{INTRODUCTION}

In contrast with the fossil record of insects in amber, those species found in laminatedcarbonate rocks are usually of larger body size, with sizes between 1 and $3 \mathrm{~mm}$ extremely rare (Martínez-Delclòs et al., 2004). This understandable bias is contradicted by the record of Rubielos de Mora Basin where the presence of minute insects, such as thrips and chalcidoids, are abundant, and where the preservation of their fine structural details, like microtrichiae and cuticular sculpturing, is detailed. This exceptional preservation, which

\footnotetext{
${ }^{1}$ Division of Invertebrate Zoology, American Museum of Natural History; Institut Cavanilles de Biodiversitat i Biologia Evolutiva, Universitat de València, Apt. 2085, E-46071, Valencia, Spain (penalver@uv.es amnh.org).

${ }^{2}$ Division of Invertebrate Zoology, American Museum of Natural History; Division of Entomology (Paleoentomology), Natural History Museum, and Department of Ecology and Evolutionary Biology, 1501 Crestline Drive-Suite 140, University of Kansas, Lawrence, Kansas 66049-2811 (msengel@ku.edu).

3 To whom correspondence may be addressed.
} 
classifies Rubielos de Mora as a KonservatLagerstätten, results from exceedingly fine burial sediments and the action of microbial mats that apparently grew on the surface of the sediment at the bottom of a meromictic lake (Peñalver, 2002; Peñalver et al., 2002b). Thus, insect carcasses were covered by a microbial mat that prevented the introduction of sediment between anatomical parts and acted as a protective structure during the carbonization and compression processes. The fossils are present in a semitransparent carbonaceous microlayer, which once comprised the microbial mat. Although exceptionally small (like their modern counterparts), the specimens presented here, taken from this unusual taphonomic setting, are remarkably well preserved with even the most minute details observable. The taxa discussed herein are rare in the fossil record of Rubielos de Mora, just as they are in fossil sites throughout the world. The presence of groups of insects rare in other paleoentomological sites rich in carbonates, the abundance and diversity of specimens, and the exceptional preservation of the fossils are features that make Rubielos de Mora one of the more important paleontological heritage sites of the Teruel Province as well as Europe as a whole (Peñalver et al., 2002a).

Herein we describe three new wasp species, one of the family Perilampidae (Chalcidoidea) and two of the family Megaspilidae (Ceraphronoidea), from the Early Miocene lacustrine sediments of Rubielos de Mora Basin (Teruel Province, eastern Spain). This work constitutes the first description of a fossil specimen of the Perilampidae and the first descriptions of megaspilids as compressions in rock. The perilampids were hitherto unknown in the fossil record. Previously there was a single reference to numerous specimens of a putative "Perilampus sp." in Baltic amber (Brischke, 1886: repeated by Larsson, 1978). Brischke (1886), however, provided no description and owing to the age of the work and the lack of any subsequent discovery of Perilampus specimens in Baltic amber, the identification must be considered dubious. Megaspilidae have been recorded by several authors previously, although specimens are still exceptionally rare; documented fossil species were found exclusively in amber, the oldest in Late Cretaceous Siberian amber (table 1). Thus the discovery of these families among the Hymenoptera from Rubielos de Mora is of significance and worth putting on formal record.

\section{GEOGRAPHICAL SETTING AND GEOLOGY}

The Rubielos de Mora Basin is located in the eastern Iberian Chain (province of Teruel, Spain), in the southernmost part of the linking zone between this chain and the Catalan Coastal ranges. The basin was at least $10 \mathrm{~km}$ long by $3 \mathrm{~km}$ wide, and the basin-fill sequence, over $800 \mathrm{~m}$ thick, consists of terrigenous and carbonate deposits of alluvial and lacustrine origin (Anadón et al., 1988, 1989, 2003). Laminated carbonates of the open lacustrine facies from Rubielos de Mora are believed to be Early Burdigalian (Early Miocene, approximately $19 \mathrm{Ma}$ : names for stages taken from Gradstein et al., 2004), corresponding to Lower Aragonian for stages of the Iberian Peninsula. Five main areas bearing fossil insects and plant remains are known in the Rubielos de Mora Basin; these are, from East to West: Río Rubielos, Los Prados-Alto de la Venta, El Bolaje de Abajo, Barranco CasasCampo de Tiro, and Cerro del Porpol (Anadón et al., 2003).

The specimens discussed herein were found in different outcrops of the Río Rubielos area, just east of the village Rubielos de Mora (fig. 1), where there are found exposures of open lacustrine facies. The open lacustrine facies consist of laminated mudstones (oil shales) with interbedded thin intervals of rhythmites (carbonate-clay, varvelike couplets) (fig. 1). The mineralogy of the carbonate laminae is mainly aragonite and minor calcite. The laminated lacustrine rock contains an abundant and diversified fauna (insects, crustaceans, molluscs, amphibians, and bird feathers) and flora (Barrón and Diéguez, 2001; Anadón et al., 2003). The flora has some particular features different from those of other European Early Miocene paleobotanical sites. These particular features can be related to the paleoclimatology and the influence of the mountains near the ancient meromictic lake. Mixed broad-leaved evergreen and coniferous 
TABLE 1

Fossil Megaspilidae ${ }^{\mathrm{a}}$

(all are preserved in amber except the Miocene Conostigmus, which are compressions in oil shales)

\author{
CRETACEOUS (145.5-65.5 Ma) ${ }^{\mathrm{b}}$ \\ Conostigmus dolicharthrus Alekseev \& Rasnitsyn, 1981 \\ Prolagynodes penniger Alekseev \& Rasnitsyn, $1981^{\mathrm{c}}$ \\ Taymyr amber (Santonian) \\ Taymyr amber (Santonian) \\ EOCENE (55.8-33.9 Ma) \\ Conostigmus antiquus Alekseev, 1995 \\ Conostigmus juveniles Brues, $1940^{\mathrm{d}}$ \\ Conostigmus resinae Brues, $1940^{\mathrm{d}}$ \\ Conostigmus succinalis Brues, $1940^{\mathrm{d}}$ \\ Lagynodes electriphilus Brues, 1940 ${ }^{\mathrm{e}}$ \\ Lagynodes primordalis Brues, $1940^{\mathrm{e}}$ \\ Lagynodes pseudocarinatus Szabó \& Oehlke, $1986^{\mathrm{e}}$ \\ Lagynodes sp. (Dessart, 1977) \\ Baltic amber (Lutetian) \\ Baltic amber (Lutetian) \\ Baltic amber (Lutetian) \\ Baltic amber (Lutetian) \\ Baltic amber (Lutetian) \\ Baltic amber (Lutetian) \\ Baltic amber (Lutetian) \\ Baltic amber (Lutetian) \\ MIOCENE (23.0-5.3 Ma) \\ Conostigmus chthonios n. sp. \\ Rubielos de Mora (Burdigalian) \\ Conostigmus lazaros $\mathrm{n}$. $\mathrm{sp}$. \\ Rubielos de Mora (Burdigalian)

\footnotetext{
${ }^{\text {a }}$ Lygocerus (= Dendrocerus) dubitatus Brues (1937) in Late Cretaceous Canadian amber is, as its name suggests,

${ }^{\mathrm{b}}$ Date ranges and names for periods, epochs, and stages are taken from Gradstein et al. (2004).

${ }^{c}$ Prolagynodes penniger was reviewed by Dessart (1987b: pg. 6).

d The Conostigmus species were redescribed by Dessart (1978).

e The fossil Lagynodes were restudied by Dessart (1977, 1987a).
} \\ dubiously placed in Megaspilidae and is therefore excluded from our listing.
}

forests that grew in a warm-temperate climate with a well-differenced dry season have been deduced (Barrón and Diéguez, 2001).

The perilampid was found in the Río Rubielos 3 outcrop (RR3), which is located on the eastern side of the Río Rubielos River. Figure 1 shows the stratigraphic log of RR3 and a photographic view of the site. The larger megaspilid was found in the Río Rubielos 2 outcrop (RR2), which is located on the southeastern side of a small tributary creek of the Río Rubielos River (see photo in fig. 1). The outcrop RR2 was excavated in 1994 at which time over 800 specimens of insects and plants were obtained (a portion of the insects from the RR2 locality were monographed by Peñalver, 1998). The recently described halictid bee, Halictus petrefactus Engel and Peñalver, was also found during this excavation, and the stratigraphic log for the RR2 outcrop was discussed therein (Engel and Peñalver, 2006).

\section{MATERIALS AND METHODS}

The sediment that had partly covered the specimens was eliminated with water and a fine pencil under magnification (see Peñalver, 1998, for methodology). Although this procedure is delicate and requires great care, it is possible to eliminate much of the sediment overlaying the fossils since the insect remains are embedded in an underlying carbonaceous microlayer that was once composed of a microbial mat. The carbonaceous films that constitute the specimens of Perilampidae and Megaspilidae (smaller specimen) have cracks (in the mesosoma and metasoma), due to the dehydration of the material after exposure and preparation, and they were treated with a hardening agent in an effort to conserve them (Peñalver, 1998, 2002). The specimens were studied and photographed under ethanol. Light coverage of remaining microscopic layers of sediment become translucent under alcohol, and the carbonaceous films that constitute the specimens contrast more intensively with respect to the matrix. Photomicrography was done with an Infinity K-2 long-distance microscope and a MicrOptics fiber-optic flash unit (www.microptics.com). The specimens were illustrated using drawing tubes attached to a Zeiss Stemi SV8 stereoscope and to a Zeiss compound microscope. Specimens are housed 

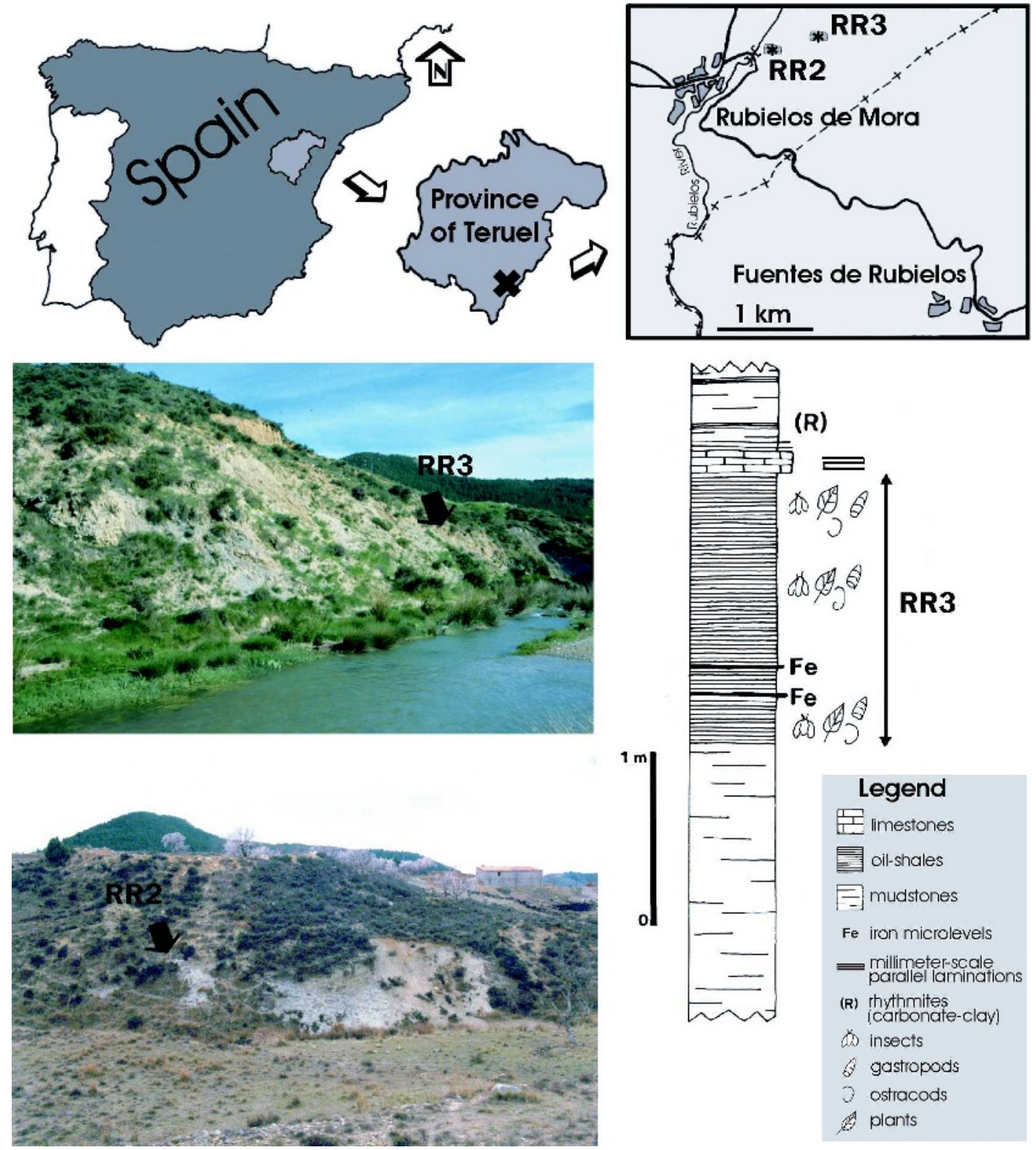

Fig. 1. Geographic location of the Río Rubielos outcrop (above), with indication of the sites of sampling named Río Rubielos 2 and Río Rubielos 3 (RR2 and RR3), and photographic views of the sites (below left); at right is a simplified stratigraphic log of Río Rubielos 3.

in the Peñalver Collection of the Natural Science Museum of Valencia (MPV-280-RM and MPV-357-RM) and in the collection of the Paleontological Museum of Zaragoza University (MPZ/97-2489), both in Spain. The Natural Sciences Museum of Valencia possesses a fireproof storage case (Tefesa, model LT-18) for the safe storage of small holotypes (Sánchez-Ferris et al., 2002). All type material of fossil insects is stored in that case in a room with precise temperature and humidity control. 


\section{SYSTEMATIC PALEONTOLOGY}

\section{SUPERFAMILY CHALCIDOIDEA LATREILLE \\ FAMILY PERILAMPIDAE LATREILLE}

The Perilampidae have, at times, been considered a subfamily of the Pteromalidae, but is now generally regarded as constituting its own family. Perilampids are typically hyperparasitoids developing on ichneumonoid (Hymenoptera) or tachinid (Diptera) primary parasitoids of symphytan Hymenoptera or Lepidoptera, or parasitoids of wood-boring beetles [Curculionidae (Platypodinae) and Anobiidae], although some species have been documented victimizing various Orthoptera, Neuroptera, and other Hymenoptera (Clausen, 1940; Goulet and Huber, 1993).

The fossil discussed herein is assigned to the Perilampidae owing to the combination of a distinct and enlarged pronotal collar, rather high metasoma in lateral aspect, transverse striate integumental sculpturing on the mesonotum, number of antennal articles, pentamerous tarsi (preserved only on one foreleg), elongate marginal vein, relatively shortened postmarginal and pterostigmal veins, and relatively robust and large body size. The ovipositor sheaths are well developed, but this is considered plesiomorphic and therefore does not exclude the fossil from the family. The enlarged pronotum and nonbulging prepectus excludes placement in Philomidinae, and the specimen best approximates the Chrysolampinae and Perilampinae. The apparently rigid attachment of the prepectus to the pronotum and the coarse mesosomal punctation are indicative of Perilampinae.

Among genera of Perilampinae (as recognized by Bouček, 1978, rather than Argaman, 1990, 1991: see Darling, 1996, for discussion of the latter classification), the exserted ovispositor is suggestive of the Nearctic genus Steffanolampus. However, this genus is in general primitive for the subfamily, and it is possible that such similarities with the fossil are merely plesiomorphic. Indeed, the pronotal collar in the fossil lacks the paired transverse elevations characteristic of Steffanolampus. The combination of a pronotal collar lacking transverse elevations, a relatively large prepectus (i.e., apparently not reduced to an exceedingly narrow triangle), an unarmed mesoscu- tellum that does not project posteriorly over the metanotum and propodeum, a subsessile metasoma (i.e., lacking a well-defined and conspicuous petiole), and an elongate marginal vein (fig. 3) is more indicative of the cosmopolitan genus Perilampus, and we, therefore, prefer to assign the species to this genus while noting that the ovipositor is a notably plesiomorphic feature relative to modern species and will perhaps eventually warrant separate generic placement.

\section{SUBFAMILY PERILAMPINAE LATREILLE}

Genus Perilampus Latreille

Perilampus renzii, new species

figures 2,3

Diagnosis: The new species can be immediately recognized owing to the plesiomorphic condition of exserted ovipositor sheaths (fig. 3a). In addition, the combination of a subsessile metasoma, enlarged pronotal collar lacking transverse elevations, large prepectus fused to the pronotum, unarmed mesoscutellum, elongate marginal vein, and pterostigmal vein shorter than the postmarginal vein serve to distinguish the species.

Description: Female. Body robust, apparently exceedingly sparsely setose, coarsely punctate except metasoma largely finely, transversely striate; total body length (as preserved and measured from front of head to posterior border of metasoma) $3.16 \mathrm{~mm}$; forewing length ca. $2.10 \mathrm{~mm}$, width $0.83 \mathrm{~mm}$. Integument black; wing membrane hyaline, with distinct microtrichiae; veins dark brown. Compound eye large, occupying nearly entire lateral portion of head; antennae articulating below level of compound eye midlength; scape length approximately equal to combined lengths of first two funicular articles; at least 10 flagellar articles evident, with some evidence of an exceedingly short, basal annellar flagellomere, yielding 11 flagellar articles in total; seven funicular articles roughly quadrate; clavus with three articles; malar space apparently linear, base of mandible near compound eye margin; mandible well developed, with at least two teeth at apex of right mandible (as preserved, somewhat incompletely preserved so a third tooth may have once been present). Pronotal collar enlarged, with 

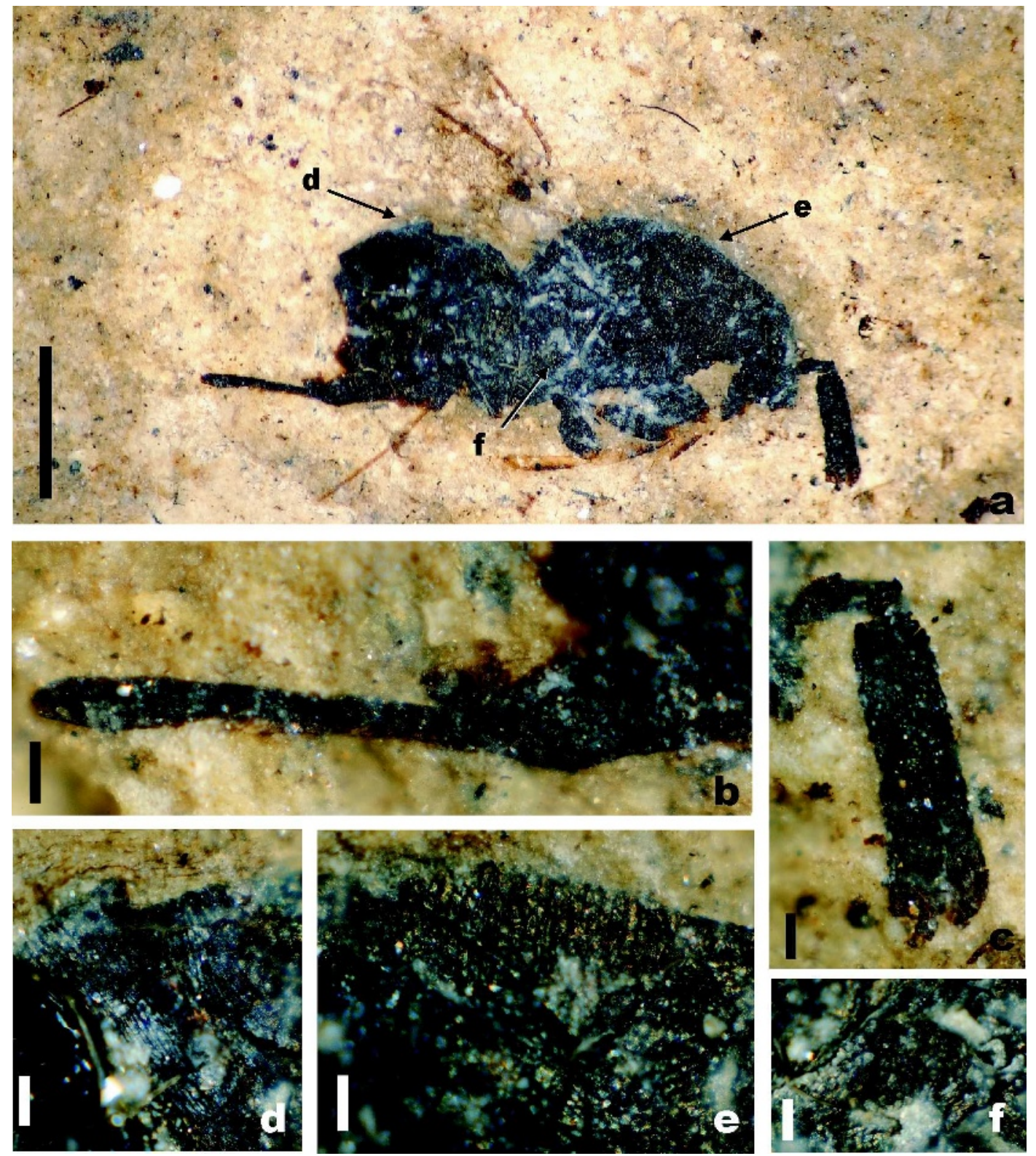

Fig. 2. Photomicrographs of Early Miocene Perilampus renzii, new species (Perilampidae), holotype female (MPV-280-RM). a. Complete lateral view of holotype. b. Ovipositor. c. Antennae. d. Detail of the linear microsculpture of the metasoma. e. Detail of the punctures on the mesoscutum. f. Detail of the punctures on the propodeum. Scale bars are $0.1 \mathrm{~mm}$ except in figure a, where it represents $1.0 \mathrm{~mm}$.

distinct dorsal surface backing up to posterior margin of head, without paired, transverse elevations; pronotum with distinct and large lateral surface; prepectus relatively large, not bulging, rigidly attached to pronotum; mesonotum with transverse, punctured striae; mesoscutellum unarmed, not projecting posteriorly over metanotum. Tarsi pentamerous (preserved only on one foreleg). Forewing with marginal vein elongate, about twice length of postmarginal vein; postmarginal and pterostigmal veins relatively short, pterostigmal 


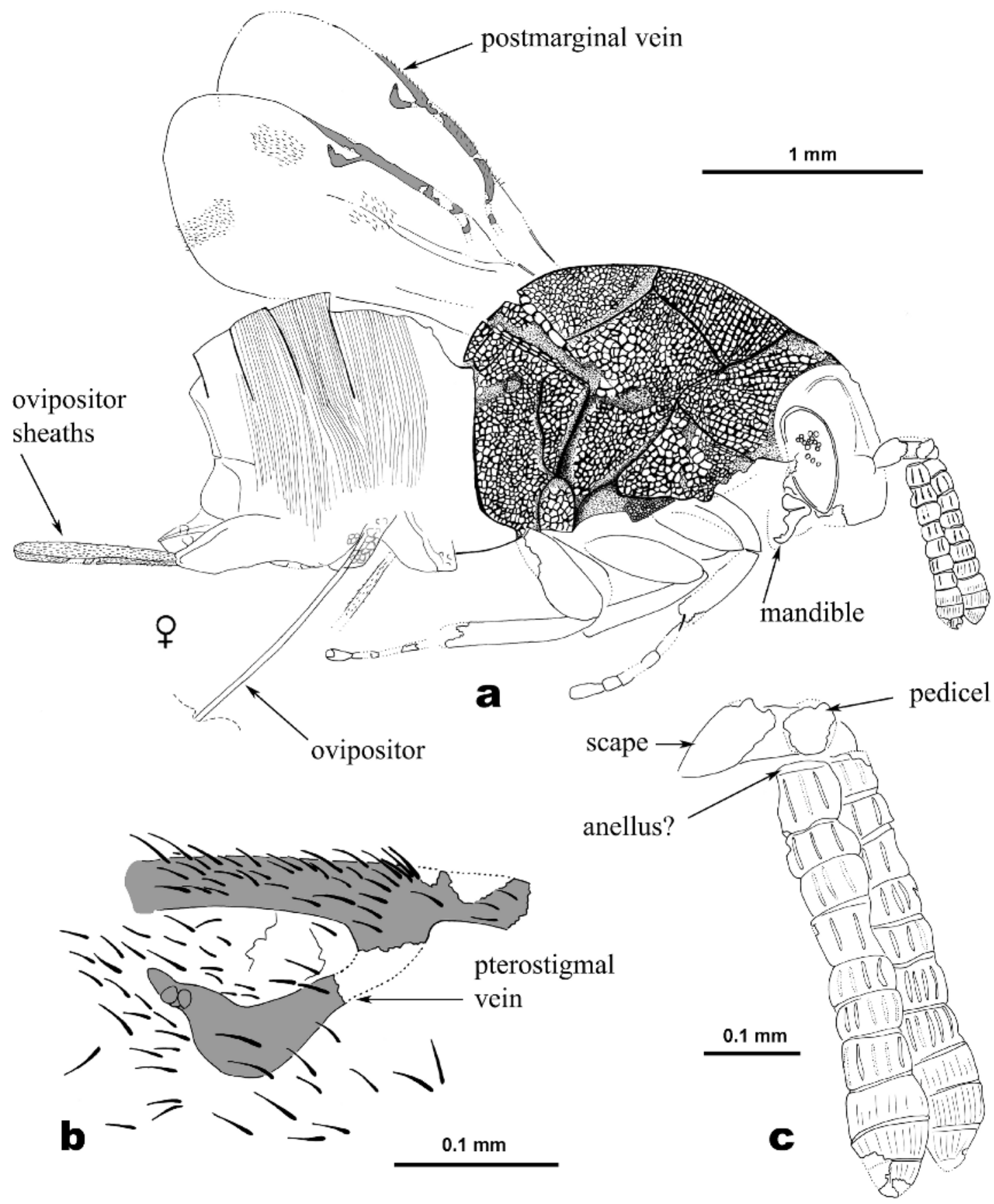

Fig. 3. Camera lucida drawings of the Perilampus renzii, new species (Perilampidae), holotype female (MPV-280-RM). a. Complete lateral view of holotype. b. Detail of pterostigmal vein of the left forewing. c. Antennae. 
vein shorter than postmarginal vein, pterostigma tapering to posterior point. Metasoma high in lateral aspect, height and length about that of mesosoma; subsessile (i.e., lacking a conspicuous petiole); ovipositor sheaths well developed and exserted, distinctly piliferous; ovipositor slender and elongate (total length indeterminate, incompletely preserved).

Holotype: Female, MPV-280-RM; holotype in small slab of oil shale with dimensions of $6.4 \times 6.2 \mathrm{~cm}$. On the same surface as that of the holotype is preserved a freshwater gastropod (MPV-279-RM) and several ostracod shells. The holotype is virtually complete and well preserved, having lost only small portions of the head, wings, legs, and ovipositor. Sculpturing can still be easily discerned on the integument and minute, setae are preserved on the wings and ovipositor valves.

Type Locality: Outcrop of Río Rubielos 3 (RR3) (see fig. 1). Early Miocene (Early Burdigalian) oil shales in Rubielos de Mora Basin, central Iberian Chain, Province of Teruel (Spain).

ETYMOLOGY: The specific epithet is a patronymic honoring Dr. Miquel De Renzi, paleontologist of the University of Valencia (Spain), for his contribution to the knowledge of the Rubielos de Mora site, in particular, and Konservat-Lagerstätten, in general.

\section{SUPERFAMILY CERAPHRONOIDEA HALIDAY FAMILY MEGASPILIDAE ASHMEAD}

The Megaspilidae is an infrequently encountered family of microhymenopteran wasps, with nearly 500 described species (although this number will assuredly double or triple as more survey and taxonomic work is undertaken on the family). Little is known of megaspilid biology, but the available information indicates a varied parasitoid lifestyle, with species attacking hosts as different as Hemiptera (Coccoidea), Neuroptera, Mecoptera (Boreidae), and Diptera (Puparia), or acting as hyperparasitoids on Hemiptera (Aphididae) via aphidiine Braconidae (Goulet and Huber, 1993). As previously mentioned (see Introduction) fossils of these minute wasps were known only as exceptionally rare inclusions in amber (summarized in table 1). It is, therefore, of significance that two megaspilids have been recovered as compressions from the Rubielos de Mora Basin.

\section{SUBFAMILY MEGASPILINAE ASHMEAD}

Genus Conostigmus Dahlbom

Conostigmus lazaros, new species

figures $4 \mathrm{a}, 5 \mathrm{a}$

Diagnosis: The fossil species can be recognized by the following combination of features: compound eyes not greatly enlarged, not encompassing the majority of the head in profile (figs. 4a, 5a); elongate scape that is nearly as long as the head capsule; more quadrate funicular articles; distalmost flagellar articles slightly larger than those near base of flagellum; apical flagellomere greatly enlarged and elongate, with gently tapered and rounded apex (fig. 5a); absence of metanotal and propodeal armature; well-developed forewings but not surpassing metasomal apex (figs. 4a, 5a); Rs well defined and elongate but disappearing well before wing apex. Conostigmus lazaros can be further distinguished from $C$. chthonios, from the same deposit (see below), by its larger body size (approximately $1.94 \mathrm{~mm}$ in total length), shorter and more robust mesosoma, more elongate head, and more quadrate funicular articles (more elongate in $C$. chthonios) (cf. figs. 4a-b, 5a-b).

Description: Female. Total body length $1.94 \mathrm{~mm}$, forewing length ca. $1.19 \mathrm{~mm}$. Integument of head and mesosoma largely dark brown to nearly black (fig. 4a); scape, pedicel, and first three flagellar articles light brown (as preserved), remainder of flagellum brown; metasomal sclerites dark brown proximally and dorsally, becoming progressively lighter until brown; preserved leg portions light brown. Head slightly elongate, with antennae articulating just below level of compound eyes; antenna geniculate; scape elongate, slightly shorter than head length, nearly as long as combined lengths of pedicel and first four flagellar articles; pedicel enlarged, distinctly longer than immediately successive flagellar articles; nine flagellar articles present (fig. 5a); funicular articles roughly quadrate; flagellum broadened slightly at apex, with distal flagellar articles slightly larger than proximal flagellar articles, apical flagellar article enlarged and elongate, with apex gently tapered and rounded. Compound eyes not greatly enlarged (not encompassing 

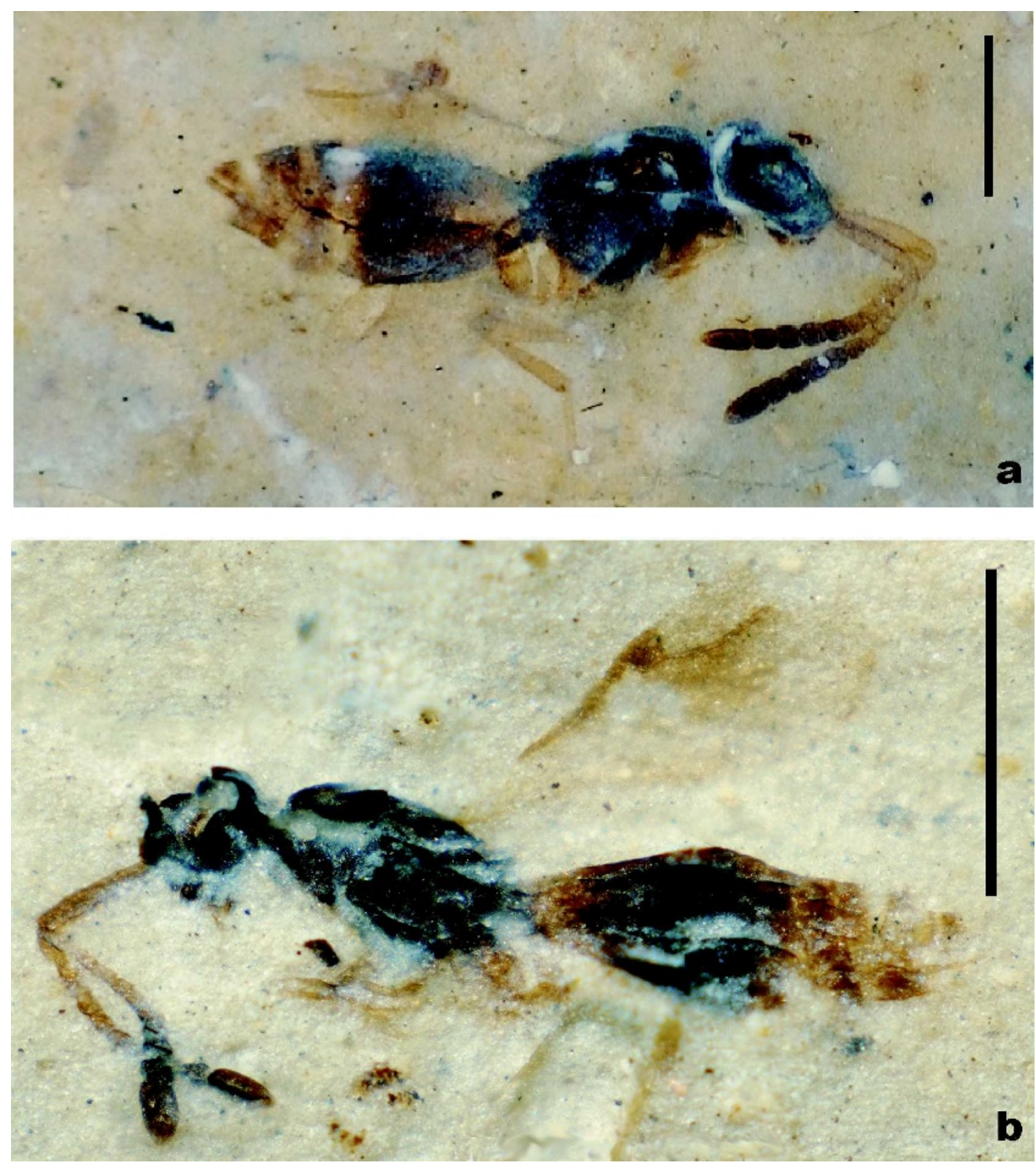

Fig. 4. Photomicrographs of Early Miocene megaspilids, Rubielos de Mora Basin. a. Conostigmus lazaros, new species, holotype female (MPZ-97/2489). b. Conostigmus chthonios, new species, holotype female (MPV-357-RM). Scale bars are $0.5 \mathrm{~mm}$.

majority of lateral surface of head as in some modern and Baltic amber species) (figs. 4a, 5a). Mesosoma robust, broadly ovoid in profile; portion of deeply impressed notaulices evident on mesoscutum, apparently converging posteriorly toward midpoint on mesoscutum (complete view of this is not possible owing to the position of preservation); mesoscutellum apparently not greatly enlarged, relatively flat in lateral aspect, not elevated above mesonotal surface; metanotum and propodeum without distinct armature. Forewings well developed, not surpassing metasomal apex; pterostigma relatively short; 


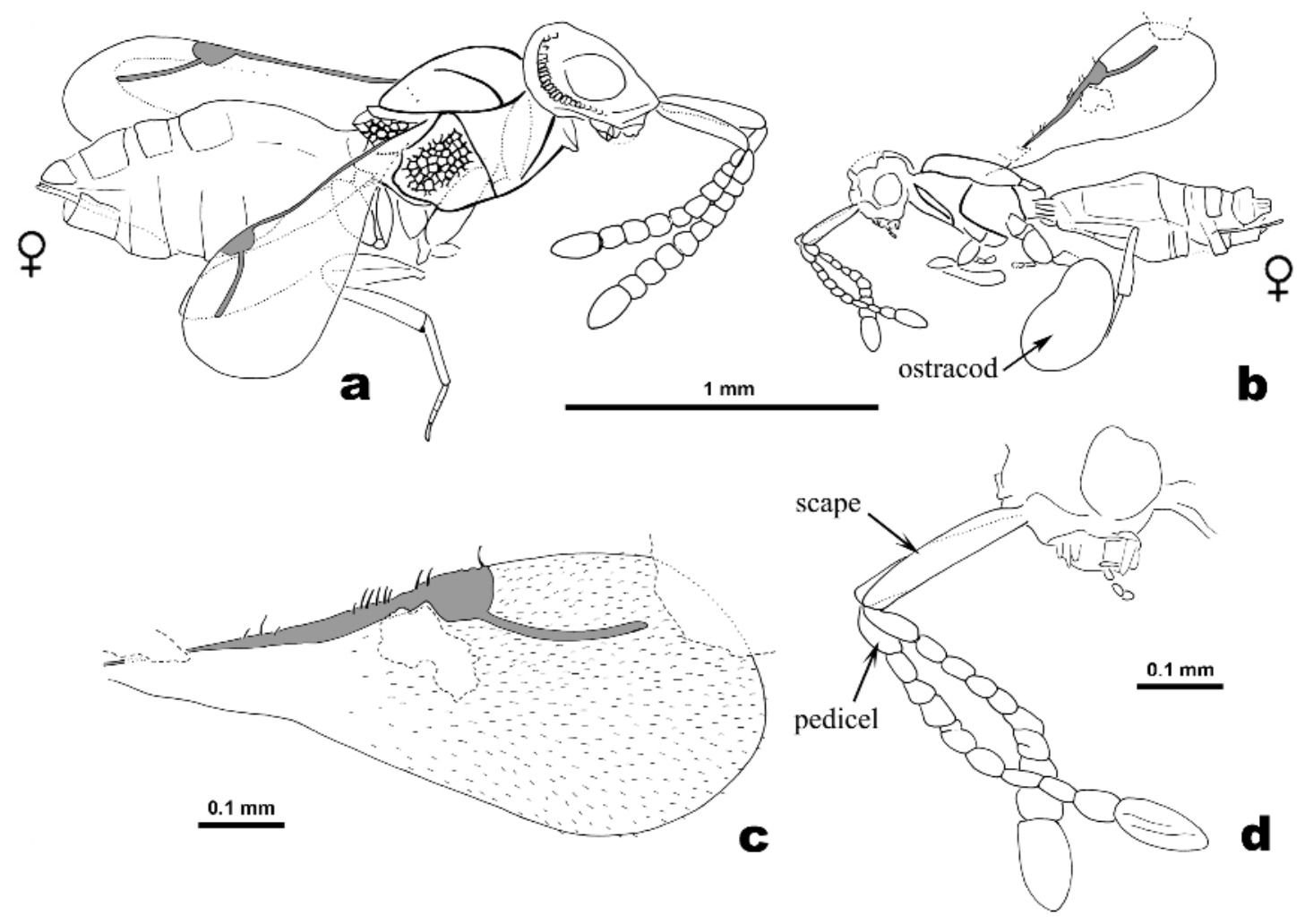

Fig. 5. Camera lucida drawings of two Early Miocene megaspilid species. a. Complete lateral view of Conostigmus lazaros, new species, holotype female (MPZ-97/2489). b.-d. Complete lateral view and details of the forewing and the antennae of Conostigmus chthonios, new species, holotype female (MPV-357-RM).

Rs well developed, elongate, terminating at distance from wing margin greater than pterostigmal length; wing membrane hyaline, veins light brown. Metasoma slightly longer than combined lengths of head and mesosoma. Male. Unknown.

HоLотуре: Female, MPZ-97/2489; holotype in a small slab of oil shale with dimensions $9.0 \times 7.2 \mathrm{~cm}$. The same surface with the holotype also contains an isolated wing of a tipulomorph (no number), a thrips of the family Aeolothripidae (MPV-97/220, now as an isolated slide preparation), and ephippia of Daphnia and shells of ostracods. The consecutive microlevel, which is exposed in some areas, contains an adult chironomid (Chironomini, RM-RR-53). The holotype is virtually complete and well preserved, having lost only some parts of the legs (some of the legs are overlapped under the mesosoma). The integument of the mesosoma partly preserves the sculpturing, and the wings preserve microtrichiae.
Type Locality: Outcrop of Río Rubielos 2 (RR2) (see fig. 1). Early Miocene (Early Burdigalian) oil shales in Rubielos de Mora Basin, central Iberian Chain, Province of Teruel (Spain).

ETYMOLOGY: The specific epithet is from the Greek and was a term generally applied to corpses, thereby referring to the fact that this is an extinct species. The name and term is a reference to the Biblical Lazarus (John 11), who died and was then brought back to life by Jesus, and is used here as an allusion to the fact that this species, although dead, has been brought back to "life" by its preservation and subsequent discovery.

Conostigmus chthonios, new species figures $4 b, 5 b-d$

Diagnosis: Refer to Diagnosis for $C$. lazaros (see above). 
Description: Female. Total body length $1.34 \mathrm{~mm}$, forewing length ca. $0.80 \mathrm{~mm}$, width $0.31 \mathrm{~mm}$. Integument of head and mesosoma largely dark brown to nearly black (fig. 4b); scape, pedicel, and first four or five flagellar articles light brown (as preserved), remainder of flagellum brown; metasomal sclerites dark brown proximally, becoming progressively lighter until brown; preserved leg portions light brown. Head globular, with antennae articulating at lower level of compound eyes; antenna geniculate; scape elongate, about as long as head length, nearly as long as combined lengths of pedicel and first four flagellar articles; pedicel enlarged, slightly longer than immediately successive flagellar articles; nine flagellar articles present (fig. 5b, d); funicular articles slightly longer than wide; flagellum broadened slightly at apex, with distal flagellar articles slightly larger than proximal flagellar articles, apical flagellar article enlarged and elongate, with apex gently tapered and rounded. Compound eyes not greatly enlarged (not encompassing majority of lateral surface of head) (fig. 5b). Mesosoma slender and elongate, narrowly ovoid in profile; mesoscutellum apparently not greatly enlarged, relatively flat in lateral aspect, not elevated above mesonotal surface; metanotum and propodeum without distinct armature. Forewings well developed, not surpassing metasomal apex (fig. 5b); pterostigma relatively short; Rs well developed, elongate, terminating at distance from wing margin greater than pterostigmal length (fig. 5c); wing membrane hyaline, veins light brown. Metasoma slightly longer than combined lengths of head and mesosoma; first tergum somewhat constricted anteriorly, with strong longitudinal striations at junction with propodeum (fig. 5b). Male. Unknown.

HolOTYPE: Female, MPV-357-RM; holotype in a small slab of oil shale with dimensions of $3.5 \times 3.2 \mathrm{~cm}$. The same surface with the holotype also contains a pupal exuvium of the family Chironomidae (MPV777-RM) and ostracod shells. The holotype is incomplete, having lost three of the wings and some portions of the legs (some of the legs are covered by an ostracod shell). Integumental sculpturing is not preserved, but microtrichiae are still discernable on the wing (fig. 5c).
Type Locality: Outcrop of Río Rubielos (RR), without more precise information about the point of sampling. Early Miocene (Early Burdigalian) oil shales in Rubielos de Mora Basin, central Iberian Chain, Province of Teruel (Spain).

ETYMOLOGY: The specific epithet is from the Greek and means "in the Earth," or "pertaining to the nether world," and is a reference to the fact that the species is known only as a compression fossil.

\section{ACKNOWLEDGMENTS}

We thank Dr. Margarita Belinchón, of the Natural Sciences Museum of Valencia, Spain (Museo de Ciencias Naturales, Valencia), and Dr. José Ignacio Canudo, of the Paleontological Museum of the Zaragoza University, Spain (Museo Paleontológico de la Universidad de Zaragoza), for curation and access to specimens. We thank the group of excavators, which helped EP during the 1994 paleontological excavation: Plinio Montoya, Esteban José Sánchez, Roser Momparler, Jordi Guillem, José Antonio Villena, and José María Tortajada. We also are grateful to Dr. Xavier Delclòs and an anonymous reviewer for careful reviews of the manuscript. This research was sponsored with a permit from the "Dirección General de Patrimonio Cultural" (D.G.A.), and with the support of the "Instituto de Estudios Turolenses" ("XII Concurso"). Partial support was also provided by National Science Foundation (USA) grants EF-0341724 and DEB-0542909 to MSE. This is contribution No. 3456 of the Division of Entomology, University of Kansas Natural History Museum.

\section{REFERENCES}

Alekseev, V.N. 1995. Conostigmus antiquus sp. n., a fossil ceraphronoid species from Baltic amber (Hymenoptera, Ceraphronoidea). Amber and Fossils 1(1): 23-25.

Alekseev, V.N., and A.P. Rasnitsyn. 1981. Late Cretaceous Megaspilidae (Hymenoptera) from amber of the Taymyr. Paleontologicheskiy Zhurnal 1981(4): 127-130. [In Russian]

Anadón, P., L. Cabrera, M. Inglés, R. Julià, and M. Marzo. 1988. The Miocene lacustrine basin of Rubielos de Mora: excursion guidebook. Barcelona: International Workshop-Field 
Seminar on Lacustrine Facies Models in Rift Systems and Related Natural Resources.

Anadón, P., L. Cabrera, R. Julià, E. Roca, and L. Rosell. 1989. Lacustrine oil-shale basins in Tertiary grabens from NE Spain (Western European rift system). Palaeogeography, Palaeoclimatology, Palaeoecology 70: 7-28.

Anadón, P., E. Peñalver, and L. Alcalá. 2003. Exceptional fossil sites in neogene basins of the central Iberian Chain (Teruel and Rubielos de Mora basins): 123-169. Teruel: EPAWorkshop 2003, Exceptional Preservation (Excursion Guide).

Argaman, Q. 1990. A synopsis of Perilampus Latreille with descriptions of new genera and species (Hymenoptera: Perilampidae), I. Acta Zoologica Hungarica 36: 189-263.

Argaman, Q. 1991. A synopsis of Perilampus Latreille with descriptions of new genera and species (Hymenoptera: Perilampidae), II. Acta Zoologica Hungarica 37: 1-19.

Barrón, E., and C. Diéguez. 2001. Estudio macroflorístico del Mioceno Inferior lacustre de la Cuenca de Rubielos de Mora (Teruel, España). Boletín Geológico y Minero 112(2): 13-56.

Bouček, Z. 1978. A generic key to Perilampinae (Hymenoptera, Chalcidoidea), with a revision of Krombeinius n. gen. and Euperilampus Walker. Entomologica Scandinavica 9(4): 299-307.

Brischke, D. 1886. Die Hymenopteren des Bernsteins. Schriften der Naturforschenden Gesellschaft in Danzig 6: 278-279.

Brues, C.T. 1937. Superfamilies Ichneumonoidea, Serphoidea, and Chalcidoidea. University of Toronto Studies, Geological Series 40: 27-44.

Brues, C.T. 1940. Calliceratidae in Baltic amber. Proceedings of the American Academy of Arts and Sciences 73(9): 265-269.

Clausen, C.P. 1940. Entomophagous insects. New York: MacGraw Hill, $x+688$ pp.

Darling, D.C. 1996. Generic concepts in the Perilampidae (Hymenoptera: Chalcidoidea): an assessment of recently proposed genera. Journal of Hymenoptera Research 5: 100-130.

Dessart, P. 1977. Contribution à l'étude des Lagynodinae (Hym. Ceraphronoidea Megaspilidae). Bulletin et Annales de la Société Royale Belge d'Entomologie 113: 277-319.

Dessart, P. 1978. Revision de trois Conostigmus de l'ambre de la Baltique (Hym. Ceraphronoidea Megaspilidae). Bulletin et Annales de la Société Royale Belge d'Entomologie 114(1-3): 50-58.

Dessart, P. 1987a. Redescription de Lagynodes pseudocarinatus Szabó \& Oehlke, 1986, de l'ambre de la Baltique (Hym. Ceraphronoidea Megaspilidae Lagynodinae). Bulletin et Annales de la Société Royale Belge d'Entomologie 123: 237-241.

Dessart, P. 1987b. Revision des Lagynodinae (Hymenoptera Ceraphronoidea Megaspilidae). Bulletin de l'Institut Royal des Sciences Naturelles de Belgique Entomologie 57: 5-30.

Engel, M.S., and E. Peñalver. 2006. A Miocene halictine bee from Rubielos de Mora Basin, Spain (Hymenoptera: Halictidae). American Museum Novitates 3503: 1-10.

Goulet, H., and J.T. Huber. 1993. Hymenoptera of the world: an identification guide to families. Ottawa: Agriculture Canada, vii + 668 pp.

Gradstein, F., J. Ogg, and A. Smith. 2004. A geologic time scale 2004. Cambridge: Cambridge University Press, xix +589 pp.

Larsson, S.G. 1978. Baltic amber - a paleobiological study. Entomograph 1: 1-192.

Martínez-Delclòs, X., D.E.G. Briggs, and E. Peñalver. 2004. Taphonomy of insects in carbonates and amber. Palaeogeography, Palaeoclimatology, Palaeoecology 203: 19-64.

Peñalver, E. 1998. Estudio tafonómico y paleoecológico de los insectos del Mioceno de Rubielos de Mora (Teruel). Teruel: Instituto de Estudios Turolenses, [i] + 177 pp.

Peñalver, E. 2002. Los insectos dípteros del Mioceno del Este de la Península Ibérica; Rubielos de Mora, Ribesalbes y Bicorp. Tafonomía y sistemática. Ph.D. diss., University of Valencia: Valencia, $550 \mathrm{pp}$.

Peñalver, E., X. Martínez-Delclòs, and E. Barrón. 2002a. Importancia patrimonial y propuesta de gestión del Konservat-Lagerstätte mioceno de Rubielos de Mora. In G. Meléndez and E. Peñalver (editors), El patrimonio paleontológico de Teruel: 209-225. Teruel: Instituto de Estudios Turolenses, $447 \mathrm{pp}$.

Peñalver, E., X. Martínez-Delclòs, and M. De Renzi. 2002b. Evidence of continental microbial mats based on the study of fossil insectsexamples from two Spanish Konservat FossilLagerstätten. In M. De Renzi, M. PardoAlonso, M. Belinchón, E. Peñalver, P. Montoya and A. Márquez-Aliaga (editors), Current topics on taphonomy and fossilization: 281-287. Valencia: Ayuntamiento de Valencia, 544 pp.

Sánchez-Ferris, E.J., E. Peñalver, and M. Belinchón. 2002. Los fósiles de Teruel depositados en el Museo de Ciencias Naturales de Valencia y su gestión informática. In G. Meléndez and E. Peñalver (editors), El patrimonio paleontológico de Teruel: 361-370. Teruel: Instituto de Estudios Turolenses, $447 \mathrm{pp}$.

Szabó, J., and J. Oehlke. 1986. Neue Proctotrupoidea aus dem baltischen Bernstein. Beiträge zur Entomologie 36(1): 99-106. 